\title{
Endoscopic Ultrasound-Guided Fine Needle Aspiration from Pericardial Lesion: A Case of Metastatic Pericardial Involvement from Breast Malignancy
}

Narendra S. Choudhary, Mukesh Nasa, Rinkesh K. Bansal, Hemanti Sarin ${ }^{1}$, Rajesh Puri

Institute of Digestive and Hepatoboliary Sciences, Medanta The Medicity, ${ }^{1}$ Department of Pathology, Medanta The Medicity, Gurugram, Haryana, India
Tissue acquisition from mediastinum is difficult due to anatomic location and presence of vessels. Endoscopic ultrasound provides access to difficult mediastinal locations that are near esophagus. We describe a case of pericardial lesion, endoscopic ultrasound guided guided fine needle aspiration cytology was done and the lesion proved to be metastatic in nature.

KEYWORDS: Endoscopic ultrasound, fine-needle aspiration, metastasis, pericardium

\section{INTRODUCTION}

$\int$ he conventional approaches of tissue acquisition aspiration (FNA) or mediastinoscopy which is invasive. As EUS scope remains in esophagus, it provides access to mediastinum from proximity and vessels are avoided easily. It has been proved to be very safe and accurate for diagnosis of mediastinal lesions that are visible from esophagus. We present a case of EUS guided FNA from pericardial lesion.

\section{CASe Report}

A 34-year-old female had mastectomy followed by chemotherapy for carcinoma breast in 2006. She had local axillary recurrence after 2 years after surgery for which she received chemotherapy. She complained back pain in 2011 and was diagnosed to have lytic spinal lesions in 2011 for which she received radiotherapy and was on kept on hormonal therapy. She was doing well. A surveillance positron-emission tomography-computed tomography in 2016 showed posterior pericardial lesion (near left atrium) measuring $3.2 \mathrm{~cm} \times 1.6 \mathrm{~cm}$ as shown in Figure 1. An endoscopic ultrasound (EUS) was done which showed irregularly thickened pericardium with encasing of a pulmonary vein as shown in Figures 2 and 3. EUS-guided fine needle aspiration (FNA) was done from pericardial thickening with $25 \mathrm{G}$ needle [Figure 4], a total of 2 passes were

\begin{tabular}{|l|l|}
\hline \multicolumn{2}{|c|}{ Access this article online } \\
\hline Quick Response Code: & Website: www.jdeonline.in \\
\hline
\end{tabular}

made, and on-site cytopathologist was kept to avoid unnecessary FNA passes. The aspirate was positive for malignant cells as shown in Figure 5.

\section{Discussion}

The malignant lesions of heart are rare. In an autopsy series of 12,485 cases, malignant lesions of heart were present in $1.23 \% .^{[1]}$ In autopsies with a known malignancy, the cardiac involvement is seen in approximately $10 \%$ of cases..$^{[2,3]}$ The common tumors with metastatic cardiac involvement in females are lungs, lymphoma, and breast. ${ }^{[1]}$ Carcinoma breast appearing as cardiac metastasis after a long time of mastectomy is

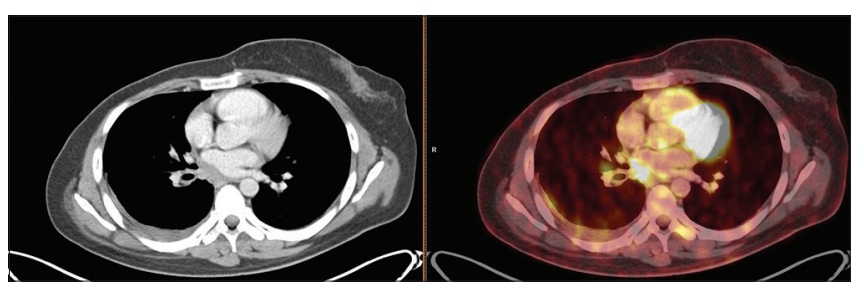

Figure 1: Positron-emission tomography contrast-enhanced computer tomography image showing fluorine deoxyglucose avidity along posterior pericardium

Address for correspondence: Dr. Rajesh Puri, Medanta The Medicity, Gurugram, Haryana, India. E-mail: purirajesh70@gmail.com

This is an open access journal, and articles are distributed under the terms of the Creative Commons Attribution-NonCommercial-ShareAlike 4.0 License, which allows others to remix, tweak, and build upon the work non-commercially, as long as appropriate credit is given and the new creations are licensed under the identical terms.

For reprints contact: reprints@medknow.com

How to cite this article: Choudhary NS, Nasa M, Bansal RK, Sarin H, Puri R. Endoscopic ultrasound-guided fine needle aspiration from pericardial lesion: A case of metastatic pericardial involvement from breast malignancy. J Dig Endosc 2018;9:138-9. 


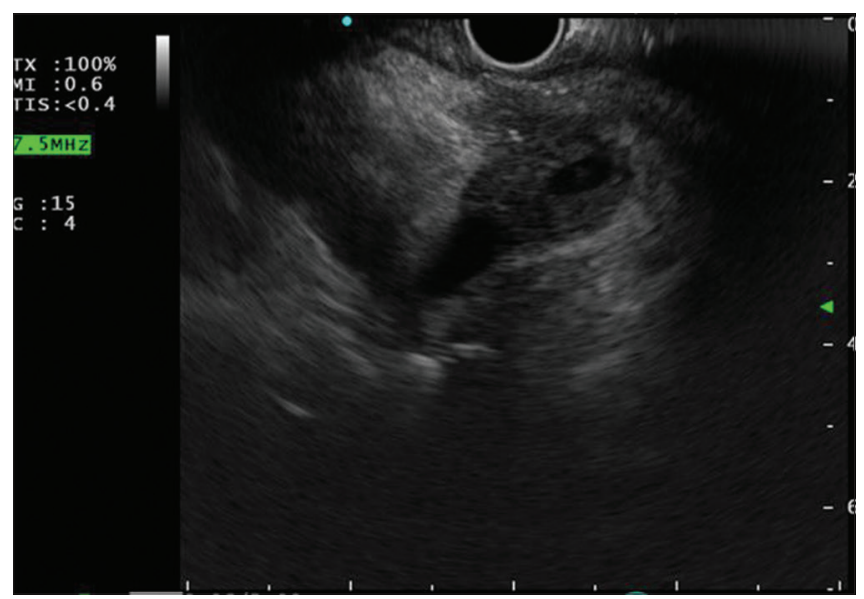

Figure 2: Endoscopic ultrasound image showing posterior pericardial deposit encasing pulmonary vein

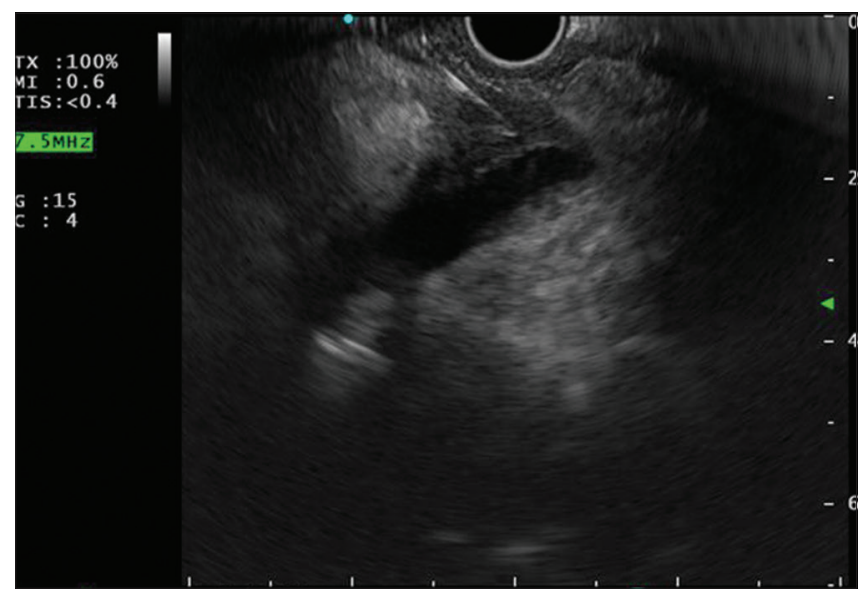

Figure 4: Endoscopic ultrasound image showing fine needle aspiration needle into posterior pericardial deposit

reported.$^{[4]}$ Use of EUS-guided FNA has been described for pericardial lesion. ${ }^{[5]}$ EUS is ideal method for FNA of such pericardial lesions as echoendoscope is placed in esophagus (proximity to target lesion), real-time monitoring of FNA procedure is possible, and it provides option of Doppler to avoid vascular structures.

\section{Declaration of patient consent}

The authors certify that they have obtained all appropriate patient consent forms. In the form the patient(s) has/have given his/her/their consent for his/ her/their images and other clinical information to be reported in the journal. The patients understand that their names and initials will not be published and due efforts will be made to conceal their identity, but anonymity cannot be guaranteed.

\section{Financial support and sponsorship}

Nil.

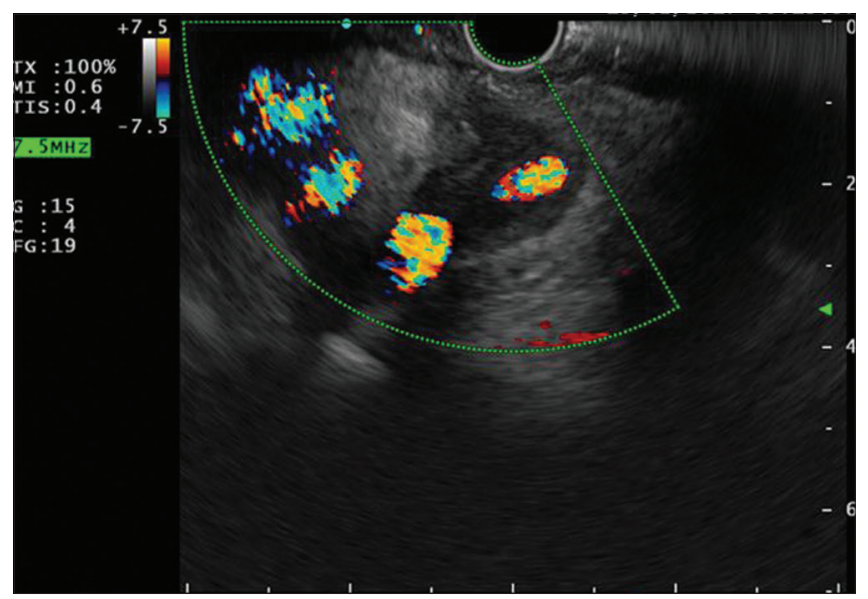

Figure 3: Endoscopic ultrasound image with Doppler showing pericardial deposit with pulmonary vein involvement

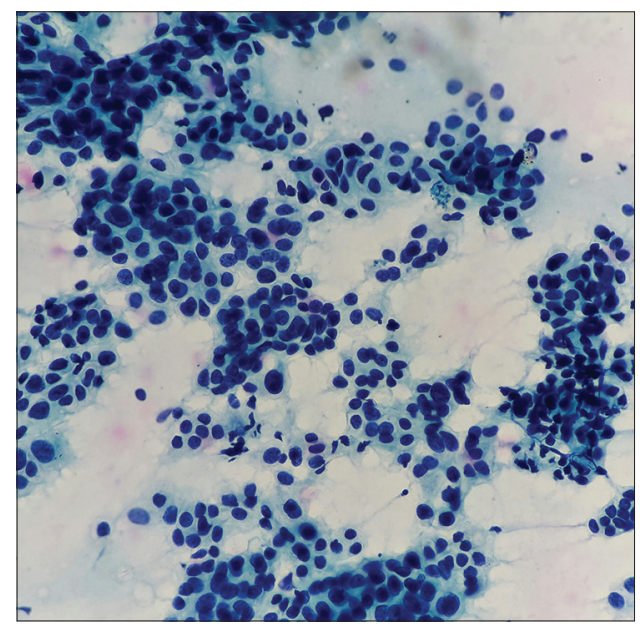

Figure 5: Microscopic image $(\times 40)$ showing pleomorphic cells with increased nuclear-cytoplasmic ratio

\section{Conflicts of interest}

There are no conflicts of interest.

\section{REFERENCES}

1. Lam KY, Dickens P, Chan AC. Tumors of the heart. A 20-year experience with a review of 12,485 consecutive autopsies. Arch Pathol Lab Med 1993;117:1027-31.

2. Abraham KP, Reddy V, Gattuso P. Neoplasms metastatic to the heart: Review of 3314 consecutive autopsies. Am J Cardiovasc Pathol 1990;3:195-8.

3. Klatt EC, Heitz DR. Cardiac metastases. Cancer 1990;65:1456-9.

4. Katalinic D, Stern-Padovan R, Ivanac I, Aleric I, Tentor D, Nikolac N, et al. Symptomatic cardiac metastases of breast cancer 27 years after mastectomy: A case report with literature review - Pathophysiology of molecular mechanisms and metastatic pathways, clinical aspects, diagnostic procedures and treatment modalities. World J Surg Oncol 2013;11:14.

5. Somani P, Sharma M, Patil A, Kumar A. Endoscopic ultrasound-guided fine needle aspiration of a pericardial mass. Endoscopy 2016;48 Suppl 1:E45-6. 